\title{
What could we learn from each other: case of human resource management practice in the Baltic countries
}

\author{
Liga Peiseniece, Tatjana Volkova \\ Management Department, BA School of Business and Finance, Riga, Latvia
}

Email address:

liga.peiseniece@ba.lv (L. Peiseniece)

\section{To cite this article:}

Liga Peiseniece, Tatjana Volkova. What Could We Learn from Each Other: Case of Human Resource Management Practice in the Baltic Countries. International Journal of Business and Economics Research. Vol. 2, No. 1, 2013, pp. 1-7. doi: 10.11648/j.ijber.20130201.11

\begin{abstract}
The purpose of the research paper is to provide an overview of similarities and differences in human resource management (HRM) in three Baltic countries and to present possibilities to improve HRM practice. The methodology of the study is based on the comparison of the results of different HRM surveys conducted in Lithuania, Estonia and Latvia during 2000 - 2010. The main findings of the investigation prove that in countries with similar history HRM develops in the similar way with little differences. The main benefits of the findings of the investigation is disclosed trends of HRM practices in Baltic countries and comparative analyses carried out.
\end{abstract}

Keywords: Human Resource Management, Baltic Countries, HRM Functions

\section{Introduction}

Human resource management (HRM) in the Baltic countries is a relatively young field and it has linkage with the history of three Baltic countries - Latvia, Lithuania and Estonia. Only twenty years ago Baltic countries regained independence and launched the changes from planned economy to market economy. In the period between 1991 and 2011 HRM has substantially developed - from personnel management to human resource management. Although the relevant changes in HRM have happened recently a comparison research about HRM practices in the Baltic countries has not been carried out. Isolated research is found in every country. The significant contributions in study of HRM in Estonia were made by Alas, Kaarelson and Svetlik, but in Lithuania - by Bučiūniene, Pundziene and Kazlauskaite. Several studies of these researchers are based on the results of Cranet survey provided deep insights into HRM performance. The Cranet surveys were conducted in Estonia three times - in 2000, 2004, 2008, but in Lithuania in 2008-2009. Several mutual surveys have been conducted by Latvian Association of Personnel Management, Research Center of BA School of Business and Finance, and Latvian Association of Business Consultants but the Cranet survey is being conducted currently in Latvia. The paper is based on the comparison of results obtained in above mentioned surveys.

The paper is the first attempt to disclose the trends of
HRM practices in Baltic countries and to compare them.

\section{Two approaches - Personnel Man-agement and Human Resource Management}

The terms Personnel Management (PM) and Human Re-source Management (HRM) have coexisted in the Baltic countries for last two decades. Although PM was used by the developed countries only until the 1980s and according to a Dictionary of Business and Management of Oxford University it involved such administrative responsibilities as interviewing job applicants, providing training, and storing personal data of employees, the transition for broader understanding of the HR role in the achieving strategic goals of a company and usage of term HRM instead of PM began only in the mid -1990s. HRM is the management of people to achieve individual behaviour and performance that will enhance an organization's effectiveness. HRM encourages individuals to set personal goals and rewards, guiding them to shape their behaviour in accordance with the objectives of the organization that employs them. As J.Storey (1995) affirmed personnel management is considered as being bureaucratic, based on rules and procedures and seen as a separate function from general management, but HRM is seen as related to the business model of organization, needs, the organization's long term plan and are the responsibility of all managers. 
The existence of PM in Baltic countries is proved by surveys where it was identified that some companies do not have long term view and developed strategic directions of development.. According to CRANET surveys in Estonia, 38 per cent of respondents in 2000 and 33 per cent of respondents in 2004 did not have written business strategy (Alas, Kaarelson, 2009); in Lithuania, 9 per cent of respondents in 2008-2009 did not have written business strategy (Kazlauskaite, Buciuniene, 2010). The authors of this article made survey of 42 large organizations in Latvia in 2009 and this survey showed that business strategy is not defined in 41 per cent of respondents (Peiseniece, Volkova, 2009).

At the same time we can see many indications which point out that the situation is changing and more and more organizations effect HRM. According to Alas (2005) the beginning of the current decade is characterized by the active development of HR strategies and policies to support overall business strategies. This phenomenon was proved by CRANET surveys in 2000 and 2004 in Estonia where positive trends in the development of strategic management were detected. The number of organizations where mission statements and strategies are formulated in written form has increased. Only the issue remains about the quality of mission statements and communication of them among staff of a company. The written corporate strategy was defined in 62 per cent of respondent enterprises in 2000 and 67 per cent of respondent enterprises in 2004 while the written HR strategy was defined in 26 per cent of respondent enterprises in 2000 and 47 per cent of respondent enterprises in 2004 (Alas, 2005).

The number of organizations where mission statements and strategy are defined and formulated in writing has increased in Estonia. A notable shift has occurred in the definition of HR strategy, which testifies to the aspiration of organisations to inte-grate HR strategy into corporate strategy (Kaarelson and Alas, 2009).

According to 2008-2009 CRANET data current $\mathrm{HRM}$ /personnel management role, competences and relev-ance in the organization are still underdeveloped in Lithua-nia. (Kazlauskaitè, Buciuniene (2010).

The development of HRM in the Baltic countries has been influenced by many external factors - directions of EU labor law, activities of HR professional societies and education institutions etc. K. Scholz and H. Böhm (2008) consider that the role of human resource management in European organizations has considerably increased since 2000, when the Council of the European Union adopted the Lisbon Strategy, the goal of which was to develop Europe as the most competitive knowledge-based economic in the world. The strategy has facilitated concentration on human resource management and development, as well as human competences and leadership.

The HRM development in an enterprise level has also been influenced by internal factors - competencies of HR manager, manager understanding what HRM is.

\section{Activity of HR Professional Societies}

HR professional associations have had the important role in the HRM development in Baltic countries. These have been founded in all three countries. To assess the impact of associations on HRM practice it is useful to evaluate their strategic goals, offered services and the number of members.

Estonian Association for Personnel Development (PARE) was established in 1992. The goal of the association is to focus more on the development of people management. The association supports the development of HR managers and management in Estonia by constantly developing the people management area, being a HR area spokesperson in the society and creating opportunities for professional development and networking for HR managers and specialists. The main activities of PARE are organizing annual HRM Conferences, seminars and focused discussion groups, training programmes in three levels and annual awards in the field of HR projects; preparing professional standard; managing qualification exams for HR specialists and managers; ensuring collaboration with governmental and other institutions in Estonia and abroad. Since 2003 PARE has been a member of European Association for People Management (EAPM). 300 legal and private persons are members of PARE.

Latvian Association of Personnel Management (LAPM) was established in 1996. The mission of LAPM is to unify human resources management professionals with aim to improve the efficiency of organisations and create human-driven environment in Latvia by developing competence in human resources management field and promoting a stra-tegic role of human resources management in organisations. The vision of LAPM is to be the best idea developer and opinion leader in human resources management field in Latvia. Strategic priorities of LAPM are to improve an added value to member organisations, to improve the publicity and authority of LAPM in Latvia, to provide and promote cooperation and mutual support between members, to develop international cooperation with HRM associations and other organisations, to attract finances. Since 2001 LAPM has been the member of the European Association of People Management (EAPM). The association unites 250 legal and 9 private members.

Similarly Association of Human Resources Professionals (PVPA) performs in Lithuania. The purpose of the associa-tion is to expand the perception of the Value of Human Resources in Lithuania, the goals are to advocate the importance of the work with Human Resources, to develop HR Professionals, upgrade their qualifications, to collect information and knowledge in Human Recourses Manage-ment and share it among the organizations and to take part in legal regulation of Human Resources related issues. The main activities of PVPA are to influence the Employer when solving important issues, to upgrade qualifications in Human Resources Management through training, to com-municate, share the information and experience with the members of the Association and also with the members 
of similar organizations in other countries. 56 legal and 22 private persons are members of PVPA.

Assessing the descriptions of the associations the authors found that the purposes of Estonian Association for Per-sonnel Development and Association of Human Resources Professionals are similar - to develop HRM area widely in a country while the purpose of Latvian Association of Per-sonnel Management is to develop human resources man-agement professionals for support of business strategies in enterprises.

The main activity of all three associations is organizing different educational and networking events for HR man-agers. All associations collaborate with governmental insti-tutions. Estonian Association for Personnel Development and Latvian Association of Personnel Management also cooperate with the European Association of People Man-agement. The EAPM forms an umbrella body of national organisations which represent HR professionals. The EAPM seeks to promote and develop knowledge of people issues, HR activities, and their importance to industry, commerce and both public and private sector administra-tion. The EAPM organises conferences, congresses and study visits; it publishes information and pursues all other objectives which directly or indirectly correspond to the aims of the Association.

One of the most experienced association in the Baltic Countries is Estonian Association for Personnel Develop-ment, it was founded at the beginning of 1990s when the term Human Resource Management was really new for many managers. The authors consider that this society has made great contribution in the development of HRM in Estonia and it unites the largest number of members in the Baltic countries. Nevertheless the association for better expanding of HRM value should update strategic goals of the association. The authors also make suggestions to Lat-vian Association of Personnel Management. One of them is to redefine strategic goals of LAMP and focus it not only to HR managers but also to executive management level. The other is to clearly describe and publish offered services by the association for members.

The information about the year of establishment of As-sociation of Human Resources Professionals in Lithuania is not published and we cannot judge how long the history of the association is. The authors suggest that PVPA should attract more companies as members in the association for achieving its goals as well as should start cooperating in-ternationally with associations from other countries. It could give possibilities to get new ideas for the improve-ment of association activities and to start cooperation with colleagues from other associations.

For rapid development of all three associations it is ne-cessary to develop strategic directions of the associations and mission statement and essential to set goals which are measurable, time specific and balanced. To ensure financial stability of an organization it is relevant to ensure quality management of an organization and to develop staff competencies of an organization.

\section{Influence of European Union Labour Law on HRM}

At the beginning of 2000s adopted European Union la-bour law directives entailed significant changes in HRM in the Baltic countries. There was established the Labour Law in Latvia in 2002, the Labour Code in Lithuania in 2003 and Employment Contract Act in Estonia in 2004.

The influence of European Union labour law on HRM has been studied by several researchers. According to Kirso (2006) Employment Contract Act, which regulates the rights and obligations of the employer and the employee, has shaped HRM practices in Estonia to a very large ex-tent: 'It has served us well throughout the establishing of free market principals'. On the one hand, these legal acts have made the work environment more employee-friendly. On the other hand, they have meant a change of HRM policies and practices for numerous organisations (Kazlauskaite, Buciuniene, 2010).

If Labour Law in Latvia and Labour Code of the Republic of Lithuania are compared, there can be found many legal provisions which impact traditional HRM functions. Provisions of both laws provide equal treatment irrespective of a person's race, skin colour, gender, age, disability, religious, political or other conviction, ethnic or social origin, property or marital status or other circumstances. The principle influences recruitment, selection and reward processes in an organization. Laws also determine a minimum wage. A minimum wage shall not be less than the minimum level determined by the State. This provision regulates reward.

The reward is also influenced by provisions which pre-scribe annual leave, maternity and paternity pay.

Labour Law in Latvia also states the main principles of recruitment, selection and employee development in Latvia. For instance, it determines that a job interview may not include such questions which are not related to the suitability of the employee for such work, as well as questions which are directly or indirectly discriminatory.

The authors of this article consider that state regulations have influenced significantly recruitment, selection, and reward and employee development. Managers and HR managers in the Baltic Countries were constrained to rede-sign approaches how to manage Human Resources at the beginning of 2000s. Next task for national legislators is to monitor how the labour law supports effective entrepre-neurship and how it protects employees and if it is neces-sary to amend it. Since the economic situation in three Bal-tic countries is currently similar, national legislators in the Baltic Countries could cooperate and find the most effec-tive and appropriate ways how to regulate separate HR processes in organizations.

\section{Research and Discussion}

\subsection{HRM practice in the Baltic Countries}

The HRM development in the Baltic Countries has also 
been formed by managers and HR managers. Many organizations realize wide spectrum of HR functions - HR planning, job analysis, recruitment, selection, adaptation, employee development, performance appraisal, reward and etc. The existence of all these HR functions was proved several surveys done by Estonian, Lithuanian and Latvian researchers and consultants. According to the results of the survey conducted by Latvian Association of Personnel Management and Latvian Association of Business Consultants in 2010 where 195 organizations participated organizations in Latvia realize different spectrum of HR functions. Figure 1 shows what kind of HR functions are actively carried out in the organizations of respondents.

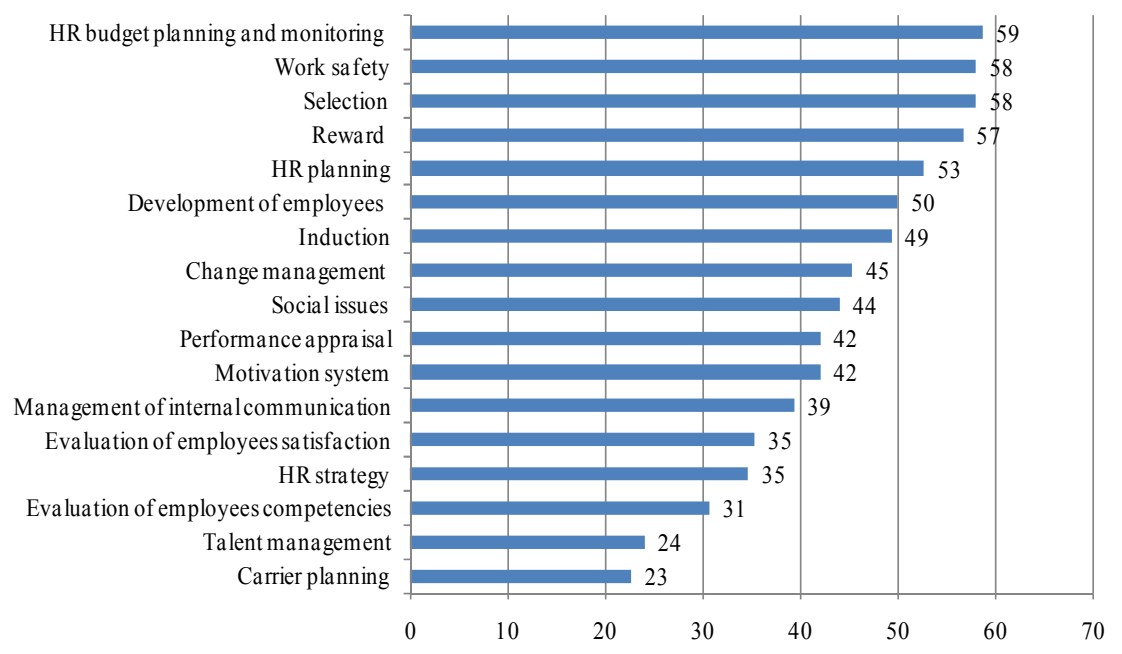

Figure 1. HRM functions carried out in the organizations of respondents in Latvia (2010).

To characterize abilities of managers and HR managers to implement well-known methods of different HR func-tions the authors will describe trends in some areas of HRM recruitment, selection and reward.

According to CRANET survey in Estonia in 2004 many companies in Estonia tend to use various methods while recruiting. The most often used method is public advertis-ing, especially circumstances where the company lacks employees with the necessary competency. Internal re-cruitment is also popular. Recruiting directly from universi-ties or other institutions providing higher education has been marginal, but in the changing circumstances this way of recruiting has become increasingly popular (Alas, 2004). Kupelyte et.al (2006) gained similar results in Lithuania. She surveyed fifteen enterprises from different sectors and of different sizes. The surveyed managers reported that the most popular source of recruitment is an advertisement in local newspapers. The second most popular source com-prises employment agencies as well as personal contacts. Quite a high number of Lithuanian managers rely on education institutions and internal recruitment sources. Used methods may account for the situation in market place in the Baltic Countries in 2004-2006. Unemployment rates were low, for instance, $4.9 \%$ in Lithuania, 6.3\% in Latvia, $5.5 \%$ in Estonia at the end of 2006 and the demand for specialists exceeded supply. Currently the economic situation has changed and unemployment rate at the end of 2010 was $18.3 \%$ in Lithuania, $18.2 \%$ in Latvia, $16.2 \%$ in Estonia. In this situation the recruitment source - education institutions has lost significance. The listed methods prove that organizations in the Baltic Countries used very traditional methods - internal recruitment, advertisement in local newspapers, recruiting from universities, personal contacts in 2004-2006. Currently the economic situation demands to economize financial resources and use cheaper and more appropriate recruitment methods - searching of $\mathrm{CV}$ date basis, advertising in internet sites and social media.

Interviews and background checks are the most preferred among selection methods in Estonia. Tests of personality, abilities and behaviour type are also frequently used. (Alas, 2005). The most popular and most used selection methods in Lithuania are a personal candidate interview and a probation period. The least popular selection methods are self-administered questionnaires and tests (Kupelyte et.al, 2006).

Currently considering large number of candidates and the difficulties to select the most appropriate candidate HR managers should use the combination of variety of selec-tion methods and to evaluate each selection process for further improvement.

The next important task after selection is reward man-agement. In Estonia the majority of organizations follow the practice of fixing salaries of managers and specialists according to individual wage agreements. Nearly one-third of businesses include company management in the profit sharing scheme. Where they can, companies frequently use a system of pay-performance. Wherever possible a number of companies have implemented a system of performance assessments. The system depends on company results, personal results and prerequisite of meeting the profit plan. In large enterprises pay systems are frequently based on job evaluation (Alas, 2009). Most Lithuanian 
companies additionally to fixed salary pay bonuses once a year only, which in the top-level management is true of 71 per cent of companies, while annual bonuses for manual workers are paid in 31 per cent of companies. Monthly bonuses are paid to top-level managers only in 11 per cent of companies, while 50 per cent of companies offer it to their manual - labour workers. In Lithuanian companies profit -sharing plans are implemented in the case of top - level management, management, specialists and clerical staff. For manual workers profit-sharing plans are applied in only 8 percent of companies. Employee stock ownership plans applied in a relatively small number of Lithuanian enterprises. The most practices include stock option plans and stock purchase plans, which are offered to top-level management in 12 and 8 per cent of companies, respectively (Hay Group, 2006). Table 1., presents forms of financial remuneration and their distribution divided by qualification of worker in Latvia in 2006. These were the results of the "Labour Market Studies" project of the European Structural Fund national programme "Labour Market Studies of the Ministry of Welfare" research "Wages and Impacting Factors" (WIF).

Table 1. Forms of financial remuneration and their distribution divided by qualification of worker

\begin{tabular}{|c|c|c|c|c|}
\hline \multirow{2}{*}{$\begin{array}{l}\text { Forms of financial remuneration } \\
\text { Fixed basic wage }\end{array}$} & \multicolumn{2}{|c|}{ High qualified workers Medium qualified workers } & \multicolumn{2}{|c|}{ Low qualified workers Total } \\
\hline & 86 & 76 & 78 & 89 \\
\hline Variable basic wage & 23 & 35 & 28 & 39 \\
\hline Monthly, quarterly premium wages & 15 & 16 & 15 & 17 \\
\hline Semi-annual, annual premium wages & 19 & 18 & 17 & 20 \\
\hline Irregular, other premium wages & 33 & 32 & 30 & 34 \\
\hline Additional payments for the enterprise results & 18 & 18 & 16 & 20 \\
\hline $\begin{array}{l}\text { Additional payments for work results of } \\
\text { team/ department }\end{array}$ & 4 & 7 & 5 & 7 \\
\hline Additional payments for individual working results & 20 & 20 & 16 & 22 \\
\hline Additional payments for additional duties & 22 & 22 & 19 & 25 \\
\hline Additional payments for unhealthy work & 7 & 10 & 9 & 11 \\
\hline Additional payments for overtime work & 29 & 38 & 37 & 40 \\
\hline
\end{tabular}

Note: The results of employers'survey of WIF research $(n=800)$. Remuneration forms are multiple answers question. Therefore, the sum of all answers is greater than $100 \%$. Qualification of employee is evaluated by subjective perception of employer.

Almost all employees surveyed in WIF research ans-wered that in principal work they had higher or lower guar-anteed (fixed) basic wage. In addition to that, a part of wage consists of a variable wage portion, perquisites and premiums. The employers' survey shows that certain dif-ferences exist also in payment of the basic wage. Firstly, in most cases $(\sim 90 \%)$ employees get the fixed basic wage; however in about $40 \%$ of cases it is complemented or even fully replaced by a variable basic wage. Secondly, the fixed or the variable basic wage is related to employee's qualifi-cation - the higher is the employee's qualification by em-ployer's subjective criteria, the greater is the possibility that this employee will get the fixed wage. Thirdly, fixed wage is related to the size of an enterprise. In micro and partially small enterprises (up to 19 employees) the fixed basic wage is paid more rarely than in other enterprises (more than 20 employees). In setting the variable wage, no variations de-pending on an enterprise size were observed. One fifth of employees surveyed in WIF research admitted that they received perquisites in their principal work for results of individual work which included percentage of enterprise profit, execution of a monthly plan etc. and fewer admitted that they got irregular premiums that could be granted as remuneration according to their merits. Those were followed by perquisites for extra hours worked which also included remuneration for overtime work, work on at holidays etc. The description of reward methods confirms that the managers of enterprises in the Baltic Countries have a good knowledge in reward management and use different forms of remuneration nevertheless they should find the most appropriate ways how to motivate employees for more effective utilization of human resources. The usage of different variable wages more frequently in companies is a method to facilitate effectiveness of employees performance and to reach goals set by company. Although additionally it is necessary to consider that the formal economic models developed by Lazaer $(1989,1991)$ indicates less variation in employees pay is efficient if it improves teamwork between employees and will more likely occur when teamwork is more important than individual performance to company objectives. 


\section{Conclusions}

The analysis of HRM practice and it impacting factors in the Baltic Countries demonstrated that HRM has developed in the period between 1991 and 2011. Many organizations have set to realize strategic management and wherewith also HRM.

The development of HRM in the Baltic countries has been influenced by many external factors - directions of EU labour law, activities of HR professional societies, edu-cation institutions, science and etc. If directions of EU la-bour law, activities of HR professional societies and HRM study programmes in higher education institutions facilitate the development of HRM in the Baltic Countries than lack of HRM research studies is the obstacle for the rapid de-velopment of HRM in Latvia and Lithuania. Regular Cra-net surveys in Estonia have educated managers and HR managers; have given information about trends of HRM practice for Estonian organizations and information for comparative analysis with other European Countries. The authors consider that is one of the most significant differ-ences in the comparison of HRM practices in the Baltic Countries.

The comparison of HR Professional Societies activities showed that associations in Estonia and Latvia have a considerable background, significant influence on HRM practice in organizations of Estonia and Latvia as well as international relationship with other national HR associations in the EU. The authors suggest to Association of Human Resources Professionals in Lithuania gaining experience from Estonian Association for Personnel Development and Latvian Association of Personnel Management how to attract more companies as members in the association and work internationally.

The analysis of the influence of European Union Labour Law on HRM in the Baltic Countries pointed out that EU regulations have influenced significantly recruitment, se-lection, reward and employee development and wherewith HRM in general. The influence of European Union Labour Law on HRM in the Baltic Countries was similar.

The study of HRM practice in the Baltic Countries con-firms that managers and HR managers in the Baltic Coun-tries have a good knowledge in HRM and they use different methods of HR functions but only a part of organizations considers that HRM is important in an organization. The research studies of the presence of HR strategy in organizations in the Baltic Countries prove it. Lack of HR strategy in many organizations in the Baltic Countries is similar. The next task for HR professionals and academics in the Baltic Countries is to promote a strategic role of human resources management in organisations.

\section{References}

[1] "Association of HR Professionals"; http://www.pvpa.lt/; Assessed January 12, 2011.
[2] "A Dictionary of Business and Management"; http://www.oxfordreference.com/views/ENTRY.html?subvie $\mathrm{w}=$ Main\&entry=t18.e3101; Assessed December 12, 2010.

[3] "Employment Contract Act", http://www.sm.ee/index.php?id $=913 \& \mathrm{~L}=1 ; \quad$ Assessed De-cember 19, 2010.

[4] "Estonian Association for Personnel Development PARE"; http://www.pare.ee/eng; Assessed January 12, 2011.

[5] "The European Association for People Management. Profile, objectives and activities"; http://www.eapm.org/about-eapm/profile-objectives-and-act ivities; Assessed January 12, 2011.

[6] "Harmonised unemployment rate by gender - total"; http://epp.eurostat.ec.europa.eu/tgm/table.do?tab=table\&lan guage $=$ en $\&$ pcode $=$ teilm020\&tableSelection $=1 \&$ plugin $=1$; Assessed December 19, 2010.

[7] Kaarelson, T., Alas, R. 2009. "Managing human resources in Estonia". M. J. Morley; Noreen Heraty; Snejina Michailova (ed.) Managing Human Resources in Central and Eastern Europe. United Kingdom: Routledge, pp.25-54.

[8] Kazlauskaite, R., Buciuniene, I. 2010. "HR function devel-opments in Lithuania", Baltic Journal of Management, 5 (2): $218-241$.

[9] Kirso, K. 2006. Interview with Kärt Kirso, HR manager of YIT Estonia Ltd, on 3 July 2006.

[10] Kupelyte,I., Klipc, O., Urbanaviciute, J., Pundziene, A. Recruitment and selection. Research report. Kaunas: Vytautas Magnus University.

[11] "Labour http://www3.lrs.lt/pls/inter3/dokpaieska.showdoc e?p id=1 91770; Assessed December 19, 2010.

[12] "Labour Law" http://www.vvc.gov.lv/advantagecms/LV/tulkoumi/dokumen ti.html?folder $=\% 2$ fdocs $\% 2$ fLRTA $\% 2$ fLikumi $\% 2$ f\&currentP age $=4$; Assessed December 19, 2010.

[13] Lazaer, E. (1989) Pay equality and industrial politics. Journal of Political economy, Vol.97, No.3, pp.561 - 80 .

[14] Lazaer, E. (1991) Labor economics and the psychology of organizations. Journal of Economic perspectives, Vol.5, No 2, pp. $88-110$.

[15] "Labour Market Studies" project of the European Structural Fund national programme "Labour Market Studies of the Ministry of Welfare" No.VPD1/ESF/NVA/04/NP/3.1.5.1./0001/0003 research "Wages and Impacting Factors" (WIF) "; http://www.lm.gov.lv/upload/darba tirgus/darba tirgus/petij umi/7_pet_en.pdf; Assessed December 19, 2010 .

[16] "Latvian Association of Personnel Management. About us"; http://www.lpva.lv/index.php/en/; Assessed January 12, 2011.

[17] Peiseniece, L., Volkova, T.. 2009. Practice of Evaluation of Human Resource Management in Latvia. Proceedings of the conference „Insights into the Sustainable Growth of Busi-ness", ISM University of Management and Economics, No-vember, Vilnius, pp.1-9.

[18] Pundziene, A., Buciuniene, I. 2009. "Managing human 
re-sources in Lithuania". Michael J. Morley; Noreen Hera-ty; Snejina Michailova (ed.) Managing Human Resources in Central and Eastern Europe. United Kingdom: Routledge, pp.55-89.

[19] Storey, J. 1992. Developments in the Management Resources: An Analytical Review. Cambridge, MA: Blackwell, pp.38.
[20] Scholz, C., Böhm, H. Human Resource Management in Europe/ Comparative analysis and contextual understanding. Routledge, Abingdon, 2008. 448 p. 